\title{
Does Race Matter? - Outcomes of the First Year Experience in a Canadian University
}

\author{
J. PAUL GRAYSON ${ }^{*}$
}

\begin{abstract}
Canadian cities are experiencing increasing ethnic and racial diversity. As a result there is a growing concern with the degree to which Canadian institutions meet the needs of a heterogeneous population. Despite this concern, as yet, there have been no systematic studies of race relations on Canadian campuses and the degree to which outcomes of the university experience are affected by race.

Data for the current study were collected at York University through a survey of 1,093 students at the time of entry in September and a survey of 1,129 students conducted in February/March of the first year. Data analysis focuses on the background characteristics of students of various races, their social and academic involvement and classroom experiences, outcomes of the first year in university, and the degree to which race affects both experiences and outcomes.

It is found that in general students of non-European origins come from families with different socio-economic characteristics than those of European descent. In addition, the nature of the university experience varies by minority status and/or race. Comparisons, however, do not always favour students of European origin. Finally, although some outcomes of the first year experience - self-assessed intellectual development and knowledge, grade point averages, and intentions to return to the university - vary by racial group; race per se explains little, if any, of the total variance. In essence, there is a considerable degree of equality in outcomes so far as race is concerned. Explanations for differences in outcomes are to be found in classroom experiences, contacts with faculty etc., and academic involvement.
\end{abstract}

* Institute for Social Research, York University 


\section{Résumé}

Les villes canadiennes connaissent actuellement une croissance importante de la diversité ethnique et raciale. On se demande toujours jusqu'à quel point les universités canadiennes répondent aux besoins d'une population hétérogène. En dépit de cette appréhension, toutefois, il n'y a pas eu une seule étude systématique ni sur les relations raciales dans les campus canadiens ni sur l'importance de la question raciale dans la vie universitaire.

Les données de l'étude que nous menons actuellement ont été recueillies à l'université York grâce à un sondage mené auprès de 1.093 étudiants au moment de la rentrée en septembre et à un autre sondage mené auprès de 1.129 étudiants en février-mars de la première année. L'analyse des données se concentre sur les antécédents des étudiants de diverses races, leur participation à la vie sociale et académique, leur expérience en classe, leurs résultats de la première année universitaire ainsi que sur l'importance de la question raciale dans leur vie étudiante.

Il a été établi qu'en général, les étudiants d'origine non européenne viennent de familles dont les caractéristiques socio-économiques sont plus variées que ceux d'origine européenne. De plus, la nature de leur expérience universitaire varie selon la minorité ethnique et raciale à laquelle ils appartiennent. Des comparaisons, toutefois, ne favorisent pas toujours les étudiants d'origine européenne. Finalement, bien que certains résultats de l'expérience de la première année, tels que le développement intellectuel et la connaissance acquise (évalués par les étudiants eux-mêmes), les moyennes de réussite scolaire et les intentions de poursuivre des études universitaires, varient selon le groupe racial, l'appartenau raciale à elle seule explique très peu toute la variance. En somme, il y a un degré considérable d'égalité dans les résultats si on prend seulement la question raciale en considération. Les explications des différences de résultats doivent être trouvées dans l'expérience en classe, dans les contacts avec le corps enseignant, etc. ainsi que dans la participation à la vie académique.

\section{Introduction ${ }^{1}$}

With increasing non-white immigration to Canada interest has grown in the extent to which non-whites have become integrated into Canadian institutions. The university is no exception in this regard; however, to date, systematic examinations of the background characteristics, university experiences, and university outcomes of students of various races have not been carried out in this 
country. If we are to avoid the simple application of perspectives developed in the United States to Canadian institutions, such inquiries must be carried out in various post-secondary institutions across the nation.

As a first step in this direction the current inquiry will examine the first year experience of students in the Faculty of Arts, and the Faculty of Pure and Applied Science at York University in Toronto. Data for the study were collected via surveys carried out prior to, or at the beginning of, classes in September, and at the end of the first year in February/March. Given that this is the first examination of its kind in Canada it would be inappropriate, before similar studies are carried out in other Canadian universities, to attempt to integrate findings into partial theories of the racial dimension of the university experience developed in the United States. More appropriate is the application to the data of some insights gained from American studies that focus on the ways in which students' background characteristics and university experiences contribute to desired university outcomes. Within this perspective race can be viewed as a category conferring potential advantage or disadvantage in terms of background characteristics known to affect outcomes and actual experiences of university life.

Consistent with this orientation it will be seen that the background characteristics of first year students at York vary by race. Similarly, first year experiences vary by race; however, the data do not support the conclusion that the experiences of students of non-European origin are uniform and necessarily negative while those of European background are positive. Moreover, while such experiences may have implications for first year outcomes the impact of race per se on outcomes is minimal. In essence, there is a considerable degree of racial equality in the outcomes of the first year.

\section{Characterization of Recent Canadian Developments}

Between 1981-91 the numbers of African and Middle Eastern immigrants to Canada increased by approximately $400 \%$; Asian/Pacific immigrants by $300 \%$; and Central/South American immigrants by $200 \%$. Over the same period the number of immigrants from the United States and Europe remained relatively constant. As a result of immigration patterns such as these it is estimated that in $199125 \%$ of the population of Metro Toronto was made up of 'visible minorities'. By 2001 the figure will be 45\% (Samuel, 1992, pp 34-35).

In view of recent immigration patterns, the experience of non-white students in the university system has been of growing concern to politicians and members of the university community. For example, as pointed out in 1992 by Richard Allen, then Minister of Education for Ontario, "we must continue our efforts to 
develop and improve the climate for under represented groups not only by making universities more accessible, but also by making sure that the necessary supports exist that will allow these individuals to succeed in their studies" (University of Toronto Bulletin, March 23, 1992). It is fair to say that when considering the situation of non-white students in Ontario's universities the common assumption is that, as in the United States, such students are at a disadvantage.

\section{Results of U.S. Studies}

Overall, the results of American research indicate a considerable disadvantage on the part of minority students. For example, in a recent summary of the U.S. situation Smedley, Miles and Harrell (1993, p. 434) write that "AfricanAmerican and other non-Asian minority students attending predominantly white colleges are less likely to graduate within five years, have lower grade point averages, experience higher attrition rates, and matriculate into graduate programs at lower rates than white students and their counterparts at predominantly Black or minority institutions." Other research on American campuses has shown that the socio-economic status of visible minority students is consistently below that of majority students (Loo \& Rolison, 1986, p. 58; Nettles, 1991, p. 87); Blacks and Chicanos may experience hostility on predominantly White campuses (Loo \& Rolison, 1986; Patterson, Aldrich, Sedlacek \& Perry, 1984; Sedlacek, 1987; White \& Sedlacek, 1987); and that there may be a negative relationship between environmental factors (such as hostility) on mainly White campuses and desired outcomes, like good grades, for minority students (Jackson \& Swan, 1991; Nettles, 1991; Smedley et al., 1993, p. 444).

Despite the relatively large amount of research on race relations on American campuses, Hurtado (1992, p. 539) nonetheless notes that "a surprisingly small number of empirical studies have focused specifically on campus racial climates." More importantly, "only a few studies include measures of campus race relations in their models of student persistence, academic achievement, and social involvement." In essence, the relationship between the university experiences of minority students and university outcomes has not received the attention it deserves. Relationships such as these are the focus of the current investigation.

More specifically, attention will focus on the experiences of first year students of different minority statuses and races entering York University in 1992 and 1993. While subsequent research will deal with the same students as they make their way through the university system, the first year experience is being singled out for the simple reason that research has shown that particularly the first few weeks of the first year of university life are a crucial period in the transition from high school to university. If strong links are not forged with (or 
within) the institution during this period it is unlikely that they will develop later (Benjamin, 1990; Upcraft \& Gardner, 1989). As a result the likelihood of leaving prior to degree completion as well as other undesired outcomes, such as low levels of achievement, is increased.

\section{A Cautionary Note}

While it may be tempting to assume that with respect to racial dynamics Canadian universities are similar to their American counterparts, there are differences between the societies that may affect racial experiences on campus. For example, as Benjamin (1994, p. 14) points out, Canada, in contrast to the United States, had only a short history of slavery and slavery never dominated the mode of production as it did in the American South prior to the civil war. In addition, while the vast majority of Blacks in the United States were born there a high proportion of Canadian Blacks are recent immigrants from Caribbean countries. More importantly, some evidence indicates that at least one outcome of the university experience, graduation, may not vary by race in Canada. While Black and Chicano students in the United States may have lower graduation rates than whites, in this country, "the university graduation rate among

Blacks, Caribbeans, and Central/South Americans is about equal to the general population; the graduation rate among Asian groups is higher than the general population" (Student Environment Study Group, 1992, p. 9). The higher rates among Asians can be attributed to the fact that they value education and are upwardly mobile.

While American studies on race relations in universities provide an obvious and welcome benchmark for research carried out in Canadian institutions, because of societal differences such as the above, in Canada, it is necessary to determine the relationships among race, university processes and experiences, and educational outcomes, before deciding on the appropriateness of integrating Canadian findings into American frameworks.

\section{The Outcomes Model}

\section{The General Perspective}

When research on the impact of universities on students is undertaken, it is useful to distinguish among three major sets of factors: pre-entry characteristics of students; environmental factors; and outcomes (Astin, 1991). Included among pre-entry characteristics are family income, parental education level, high school attainment, gender, and so on. Each of these may be linked to university success. Environmental factors include curriculum, peer climate, and 
the degree to which the institution facilitates the social and academic involvement of students. Outcomes can be defined as, "those aspects of the student's development that the institution either does influence or attempts to influence through its educational programs and practices" (Astin, 1991, p. 38).

In general, holding pre-entry characteristics constant, environmental factors may have implications for certain university outcomes. For example, two universities may have different effects on students who are similar in terms of their prior academic achievement and social background. It is these effects that are important in assessing the relevance of the university experience.

\section{Social and Academic Involvement}

Among environmental variables that have been found to have an important impact on various outcomes, few, if any, have been found to be as important as social and academic involvement. Organized or informal associations with students can be identified as social integration/involvement. Participation in the formal curriculum, interactions with faculty, academic achievement, and participation in academic activities can be viewed as academic integration/involvement.

In his massive study of university and college students in the United States, Astin came to two general conclusions with regard to certain aspects of social and academic involvement. First, "the student's peer group is the single most potent source of influence on growth and development during the undergraduate years" (Astin, 1993, p. 398). Second, "next to the peer group, the faculty represents the most significant aspect of the student's undergraduate development" (Astin, 1993, p. 41). Other studies have pointed in the same direction (Centra \& Rock, 1971; Endo \& Harpel, 1983; Pascarella \& Terenzini, 1976, 1977, 1979a, 1979b, 1991; Pascarella, et al., 1983a and 1983b; Volkwein et al., 1985; Astin \& Astin, 1992).

\section{Classroom Characteristics}

Although the formal and informal components of academic and social involvement may be contributory to certain university outcomes commuter students, such as those at York University, because of the relatively limited time spent on campus may have less opportunity than students at residential universities to engage in activities other than those associated with the formal curriculum. As a result, it might be reasonable to assume some less desirable student outcomes from commuter as compared to residential universities. This expectation of less desirable outcomes from commuter institutions was borne out in a classic study by Chickering (1974) and in research completed by others (Astin \& Astin, 1992, pp. 7-9; Astin, 1993; Dietsche, 1990; Grayson, 1994a; Welty, 1976) 
Because of the relative anonymity of the commuter experience, it has been argued in a study of science students at York University (Grayson, 1994a) that in commuter institutions what goes on in the classroom is the primary link between the students and the institution. As a result, classroom characteristics are important to a number of desired outcomes. For example, in the York study, it was determined that satisfaction with instruction and the perceived importance of class topics to future career success particularly affected a number of desired outcomes of the first year such as marks, program satisfaction, and intention to return to the university. By way of comparison, measures like contacts with professors, and participation in social and informal academic activities, that have been found to be important to various outcomes in residential universities, were of no consequence.

The general importance of specific classroom experiences to desired outcomes has also been noted in studies of adult students whose university experience is primarily that of the commuter (Ashar \& Skenes, 1993; Beer \& Darkenwald, 1989; Darkenwald \& Gavin, 1987; Langenbach \& Aagard, 1990). In view of findings such as these, it is essential to look at the nature of the classroom experience as distinct from traditional measures of academic and social involvement and contacts with faculty.

A final feature of the classroom that warrants consideration is the degree to which students are presented with a variety of perspectives. As Astin (1993, p. 431) points out, "the weight of empirical evidence shows that the actual affects on student development of emphasizing diversity and of student participation in diversity activities are overwhelmingly positive".

\section{Nature of the Sample}

York is a large commuter university with approximately 26,000 full-time, 15,000 part-time, and 3,500 graduate students located on the suburban fringe of Metropolitan Toronto. Roughly $10 \%$ of undergraduate students live in residence on campus. Overall, approximately $21 \%$ of students are members of visible minority groups. The non-minority portion of the student body is made up of, among others, large numbers of students of Italian, Portuguese, Greek, and other non-English origins.

For the current study, the extent to which first year students might have background characteristics, university experiences, and first year outcomes that vary by minority status and/or race was determined through analyzing the results of two surveys that are part of an on-going program of student studies at York University. ${ }^{2}$ In 1992-93 students entering the Faculty of Pure and Applied 
Science were surveyed on the first day of classes, in November, and in March. In 1993-94 students entering the Faculty of Arts and Atkinson College (the evening operation of York University) were surveyed prior to the commencement of classes and in March. The current study is based on the September and March samples from Pure and Applied Science and Arts students. Because they are predominantly 'mature' part-time students, data on Atkinson students will be analyzed in a separate study.

The number of cases for the combined September samples is 1093; for the combined March samples the number of cases is 1129. Both samples were appropriately weighted. Overall, the Faculty of Pure and Applied Science and the Faculty of Arts enroll approximately $80 \%$ of all full-time first year students entering York University.

The response rates for the September survey of science students was approximately $86 \%$ and for Arts students approximately $70 \%$. March response rates for Science and Arts were somewhat lower with an approximate $68 \%$ response rate for Science and $54 \%$ for Arts. Although roughly $70 \%$ of students provided their student numbers on each survey, it was not always the same $70 \%$. As a result longitudinal analyses are not feasible.

\section{Background Characteristics}

A study conducted by the Institute for Social Research at York University found that overall, in 1991, approximately $21 \%$ of York students in all years defined themselves as members of a visible minority group (usually, but not always, on the basis of appearance). In the first year surveys conducted for this study, approximately $26 \%$ of students self-identified as members of a visible minority. This figure corresponds to the visible minority population of Toronto as a whole. As has been indicated elsewhere, however, the whole idea of visible minority is problematic (Grayson 1994c, 1994d). For example, at York University, roughly $50 \%$ of students who grew up speaking Chinese in the family do not regard themselves as members of a visible minority group. As a result, for heuristic purposes, in this study all students who spoke Chinese in their family while growing up were defined as members of a visible minority group. In general the minority category will be made up of Blacks and students of East Indian, Chinese, and 'other' origins. Among all racial groups approximately $63 \%$ of students are female.

If race rather than visible minority status is examined, approximately $74 \%$ of all students can be viewed as of European origin. Students of Chinese, Black, East Indian, and 'other' non-European origins make up about 9\%, 5\%, 
$4 \%$, and $10 \%$ of the first year student population. Although the designation 'Chinese' should be viewed as an ethnic rather than as a racial category, in this study it is used to signify distinct physical characteristics. Similar arguments could be made regarding the category 'East Indian' which, in reality, is a geographical origin characteristic.

September survey data show that $50 \%$ of minority and $18 \%$ of majority students were foreign born. Among minorities, $84 \%$ of Chinese students were not born in Canada. The numbers of the foreign born among Blacks and students of East Indian and 'other' origins were $48 \%, 50 \%$, and $44 \%$ respectively.

With respect to language spoken in the home while growing up, 74\% of students of European origin reported English. The group with the greatest number who spoke English in the family was the Blacks: $93 \%$ came from families in which English was spoken. The number of East Indian origin students who spoke English in the family was $76 \%$. For students of Chinese origin the number was only $26 \%$. In terms of any advantage that might derive from growing up in a family in which the first language was English, it would appear that individuals of European origin have no greater advantage than Black students or those of East Indian origin.

Survey data also indicate that for both minority and non-minority groups approximately one quarter of entering students come from families in which the father had completed college or university. On average $17 \%$ of mothers had the same level of education with little difference between minority and non-minority groups. Despite these overall similarities the parental education of Black students is the lowest while that of parents of students of East Indian origin is the highest.

Although minorities and non-minorities did not differ in terms of parental education, the annual family incomes of minorities as determined in the September survey are significantly lower than those of non-minorities. For example, only $39 \%$ of the families of minority students earned $\$ 50,000$ or more per year. The corresponding figure for non-minorities is $56 \%$. Within the minority category the lowest family incomes were reported by Blacks and those of Chinese and 'other' origins: approximately $62 \%$ of each reported family incomes of less than $\$ 50,000$ per year. Among students with East Indian ancestry, $55 \%$ reported incomes this low. By way of comparison, only $44 \%$ of the families of European origin students had incomes below $\$ 50,000$ (according to Statistics Canada the average family income in Ontario in 1992 was $\$ 58,634$ ). Differences such as these should be seen in connection with the fact noted above that levels of parental education did not differ by minority status. This fact notwithstanding, it is impossible to determine if differential family incomes 
are a reflection of length of time in Canada, particular skills of parents, lack of facility with language, the number of working adults in the family, or labour market discrimination.

Survey data indicate that the summer earnings of minority students are significantly lower than those of non-minorities: only $20 \%$ of the former compared to $43 \%$ of the latter earned $\$ 2,001$ or more. The lowest summer earnings were among students of Chinese origin, only $7 \%$ of whom earned $\$ 2,001$ or more. Among Blacks and students of East Indian and 'other' origins approximately $25 \%$ earned $\$ 2,001$ or more.

Finally, the Ontario Academic Credit (OAC) marks of students of Black, East Indian, Chinese, 'other', and European ancestry were $77 \%, 80 \%, 78 \%$, $76 \%$, and $79 \%$ respectively. Moreover, while absolute differences are not large, they are statistically significant.

\section{Social and Academic Involvement}

\section{Social Involvement}

Data on social involvement as measured in the February/March survey are summarized in Table 1. Distinctions in this and following tables have been made on the basis of minority and majority status and race. ${ }^{3}$ (In the following discussion these distinctions will be referenced as 'status' and 'race'.) As will be seen, simply viewing students in terms of status often obscures important differences based on race. Potential gender differences will be dealt with in regression analyses later.

Also in this and following tables, row totals provide the total number of students in the race categories who provide the answer listed on the left side of the table. ${ }^{4}$ Numbers in columns show the number of students in each minority or race group who give the answer to the left of the table. Where means are given, the numbers refer to the number of students on which the mean is based. These procedures were followed so that the amount of data presented would be kept to a manageable level.

The first thing of note in Table 1 is the statistically significant difference between minority and majority students with respect to participation in campus clubs and/or organizations. On average, visible minority students participated in .61; majority students in .47 . Differences based on race are not statistically significant.

While there are no differences based on status or race with respect to the number of sports activities participated in, minority students watched fewer sports over the academic year than majority students. The respective figures for 
Table 1

Social Involvement

\begin{tabular}{|c|c|c|c|c|c|c|c|c|}
\hline & \multicolumn{2}{|c|}{ Status } & \multicolumn{6}{|c|}{ RACE } \\
\hline & Minority & Majority & Black & East Indian & Chinese & Other & European & Row Total \\
\hline No. Clubs Organizations* & $\begin{array}{c}.61 \\
(304)\end{array}$ & $\begin{array}{c}.47 \\
(808)\end{array}$ & $\begin{array}{c}.70 \\
(56)\end{array}$ & $\begin{array}{c}.72 \\
(60)\end{array}$ & $\begin{array}{c}.49 \\
(101)\end{array}$ & $\begin{array}{c}.63 \\
(91)\end{array}$ & $\begin{array}{c}.47 \\
(809)\end{array}$ & $\begin{array}{c}.51 \\
(1,117)\end{array}$ \\
\hline No. Sports Activities Participated & $\begin{array}{c}.37 \\
(305)\end{array}$ & $\begin{array}{c}.51 \\
(806)\end{array}$ & $\begin{array}{c}.43 \\
(56)\end{array}$ & $\begin{array}{c}.34 \\
(60)\end{array}$ & $\begin{array}{c}.25 \\
(103)\end{array}$ & $\begin{array}{c}.51 \\
(91)\end{array}$ & $\begin{array}{c}.50 \\
(807)\end{array}$ & $\begin{array}{c}.47 \\
(1,116)\end{array}$ \\
\hline No. Sports Activities Watched* & $\begin{array}{c}.53 \\
(307)\end{array}$ & $\begin{array}{c}.80 \\
(807)\end{array}$ & $\begin{array}{c}.93 \\
(56)\end{array}$ & $\begin{array}{c}.29 \\
(61)\end{array}$ & $\begin{array}{c}.18 \\
(103)\end{array}$ & $\begin{array}{c}.82 \\
(91)\end{array}$ & $\begin{array}{c}.80 \\
(808)\end{array}$ & $\begin{array}{c}.73 \\
(1,118)\end{array}$ \\
\hline Weekly Pub Visits** & $\begin{array}{c}.49 \\
(302)\end{array}$ & $\begin{array}{c}63 \\
(801)\end{array}$ & $\begin{array}{c}.40 \\
(56)\end{array}$ & $\begin{array}{c}.85 \\
(62)\end{array}$ & $\begin{array}{c}.16 \\
(99)\end{array}$ & $\begin{array}{c}.61 \\
(90)\end{array}$ & $\begin{array}{c}.63 \\
(802)\end{array}$ & $\begin{array}{c}.59 \\
(1,109)\end{array}$ \\
\hline No. New Friends & $\begin{array}{c}13.4 \\
(293)\end{array}$ & $\begin{array}{c}14.5 \\
(776)\end{array}$ & $\begin{array}{l}13.6 \\
(56)\end{array}$ & $\begin{array}{l}16.0 \\
(58)\end{array}$ & $\begin{array}{l}11.9 \\
(96)\end{array}$ & $\begin{array}{l}12.7 \\
(87)\end{array}$ & $\begin{array}{c}14.5 \\
(777)\end{array}$ & $\begin{array}{c}14.2 \\
(1,074)\end{array}$ \\
\hline Hrs. Week With New Friends*** & $\begin{array}{c}2.5 \\
(280)\end{array}$ & $\begin{array}{c}3.4 \\
(721)\end{array}$ & $\begin{array}{c}1.7 \\
(47)\end{array}$ & $\begin{array}{c}2.7 \\
(56)\end{array}$ & $\begin{array}{c}1.7 \\
(95)\end{array}$ & $\begin{array}{c}3.7 \\
(85)\end{array}$ & $\begin{array}{c}3.4 \\
(722)\end{array}$ & $\begin{array}{c}3.1 \\
(1,005)\end{array}$ \\
\hline$\%$ Friends Visible Minorities*** & $\begin{array}{c}60.7 \% \\
(297)\end{array}$ & $\begin{array}{c}29.8 \% \\
(757)\end{array}$ & $\begin{array}{c}65.5 \% \\
(55)\end{array}$ & $\begin{array}{c}62.1 \% \\
(60)\end{array}$ & $\begin{array}{c}58.1 \% \\
(96)\end{array}$ & $\begin{array}{c}58.4 \% \\
(90)\end{array}$ & $\begin{array}{c}29.9 \% \\
(757)\end{array}$ & $\begin{array}{c}38.6 \% \\
(1,058)\end{array}$ \\
\hline $\begin{array}{ll}* & \text { F sig. } .05 \text { level status } \\
* * & \text { F sig. } .05 \text { level race } \\
* * * & \text { F sig. } 05 \text { level status and race }\end{array}$ & & & & & & & & \\
\hline
\end{tabular}


this dimension are .53 and .80 . Again, race based differences are not statistically significant.

Table data indicate that while majority students make on average .63 pub visits per week, the figure for minorities is .49; however, differences are not statistically significant. Race based differences are statistically significant. Whereas students of East Indian origin make on average .85 pub visits per week, students of Chinese origin make only .16. The visits of 'others' and students of European origin are roughly the same, .61 and .63 respectively. On average Black students make .40 visits per week.

Although making new friends was identified as a problem for a number of students (Grayson, 1994b), differences based on status and race regarding the number of new friends made since September are not statistically significant. On average students made 14.2 new friends since the beginning of school.

Differences emerge when the amount of time spent with new friends is examined. While majority students report 3.4 hours per week associating with new friends, the figure for minorities is only 2.5 hours a week. Racial variations are even wider. For example, Blacks and students of Chinese origin spend only 1.7 hours per week with new friends whereas 'others' and students of European origin report 3.7 and 3.4 hours per week respectively. Students of East Indian origin average 2.7 hours per week with friends met since September.

Not surprisingly, data in Table 1 also show that visible minority students have friends who are also visible minorities to a greater extent than non-minorities. The former report that $60.7 \%$ of their friends (not those made in university since September) belong to visible minority groups; the latter only $29.8 \%$. When race is examined it is seen that Blacks have more visible minority group friends - $65.5 \%$ - than any other racial group; however, figures for students of East Indian, Chinese, and 'other' origins are not much lower than those for Blacks. Understandably, the largest difference is between those of European origin and all others. Figures such as these may indicate a considerable degree of self-imposed segregation on the part of students of various origins. Status and race differences are statistically significant for both groups.

\section{Academic Involvement}

Figures pertaining to academic involvement as determined in the survey conducted in February/March are outlined in Table 2. With respect to out-ofclass contacts with faculty of ten minutes or more per month, differences based on status and race are not statistically significant and the average number of contacts is 3.2 . 
Table 2

Academic Involvement

\begin{tabular}{|c|c|c|c|c|c|c|c|c|}
\hline & \multicolumn{2}{|c|}{ STatus } & \multicolumn{6}{|c|}{ RACE } \\
\hline & Minority & Majority & Black & East Indian & Chinese & Other & European & Row Total \\
\hline Faculty Contacts Month & $\begin{array}{c}3.6 \\
(306)\end{array}$ & $\begin{array}{c}3.1 \\
(808)\end{array}$ & $\begin{array}{c}2.7 \\
(56)\end{array}$ & $\begin{array}{c}3.8 \\
(62)\end{array}$ & $\begin{array}{c}4.3 \\
(102)\end{array}$ & $\begin{array}{c}3.0 \\
(91)\end{array}$ & $\begin{array}{c}3.1 \\
(811)\end{array}$ & $\begin{array}{c}3.2 \\
(1,121)\end{array}$ \\
\hline TA/Demonstrator Contacts Month* & $\begin{array}{c}2.3 \\
(302)\end{array}$ & $\begin{array}{c}1.9 \\
(796)\end{array}$ & $\begin{array}{c}2.0 \\
(56)\end{array}$ & $\begin{array}{c}3.1 \\
(61)\end{array}$ & $\begin{array}{c}2.1 \\
(100)\end{array}$ & $\begin{array}{c}2.2 \\
(89)\end{array}$ & $\begin{array}{c}1.9 \\
(799)\end{array}$ & $\begin{array}{c}2.0 \\
(1,104)\end{array}$ \\
\hline Staff Contacts Month* & $\begin{array}{c}2.4 \\
(298)\end{array}$ & $\begin{array}{c}1.7 \\
(807)\end{array}$ & $\begin{array}{c}1.7 \\
(55)\end{array}$ & $\begin{array}{c}2.6 \\
(60)\end{array}$ & $\begin{array}{c}1.7 \\
(99)\end{array}$ & $\begin{array}{c}2.1 \\
(89)\end{array}$ & $\begin{array}{c}1.6 \\
(809)\end{array}$ & $\begin{array}{c}1.7 \\
(1,112)\end{array}$ \\
\hline Academic Activities 2 Months & $\begin{array}{c}1.0 \\
(296)\end{array}$ & $\begin{array}{c}1.0 \\
(795)\end{array}$ & $\begin{array}{c}1.0 \\
(55)\end{array}$ & $\begin{array}{c}1.2 \\
(60)\end{array}$ & $\begin{array}{c}0.9 \\
(100)\end{array}$ & $\begin{array}{c}0.9 \\
(87)\end{array}$ & $\begin{array}{c}1.0 \\
(797)\end{array}$ & $\begin{array}{c}1.0 \\
(1,097)\end{array}$ \\
\hline Hrs/Week on Campus & $\begin{array}{c}23.8 \\
(293)\end{array}$ & $\begin{array}{c}24.4 \\
(781)\end{array}$ & $\begin{array}{l}23.6 \\
(52)\end{array}$ & $\begin{array}{l}25.2 \\
(60)\end{array}$ & $\begin{array}{c}22.1 \\
(100)\end{array}$ & $\begin{array}{l}25.2 \\
(85)\end{array}$ & $\begin{array}{c}24.4 \\
(787)\end{array}$ & $\begin{array}{c}24.3 \\
(1,080)\end{array}$ \\
\hline Current Courses & $\begin{array}{c}4.2 \\
(308)\end{array}$ & $\begin{array}{c}4.2 \\
(811)\end{array}$ & $\begin{array}{c}4.0 \\
(57)\end{array}$ & $\begin{array}{c}4.2 \\
(61)\end{array}$ & $\begin{array}{c}4.2 \\
(104)\end{array}$ & $\begin{array}{l}4.1 \\
(91)\end{array}$ & $\begin{array}{c}4.2 \\
(812)\end{array}$ & $\begin{array}{c}4.2 \\
(1,124)\end{array}$ \\
\hline Courses Dropped & $\begin{array}{c}0.6 \\
(309)\end{array}$ & $\begin{array}{c}0.5 \\
(803)\end{array}$ & $\begin{array}{l}.57 \\
(57)\end{array}$ & $\begin{array}{c}.42 \\
(62)\end{array}$ & $\begin{array}{c}.67 \\
(104)\end{array}$ & $\begin{array}{l}.55 \\
(91)\end{array}$ & $\begin{array}{c}.49 \\
(803)\end{array}$ & $\begin{array}{c}.51 \\
(1,117)\end{array}$ \\
\hline \% Lectures Attended & $\begin{array}{c}91.6 \% \\
(308)\end{array}$ & $\begin{array}{c}90.8 \% \\
(807)\end{array}$ & $\begin{array}{c}90.3 \% \\
(56)\end{array}$ & $\begin{array}{c}95.3 \% \\
(62)\end{array}$ & $\begin{array}{c}90.5 \% \\
(104)\end{array}$ & $\begin{array}{c}91.1 \% \\
(91)\end{array}$ & $\begin{array}{c}90.8 \% \\
(808)\end{array}$ & $\begin{array}{c}91.1 \% \\
(1,121)\end{array}$ \\
\hline$\%$ Tutorials/Labs Attended* & $\begin{array}{c}85.2 \% \\
(300)\end{array}$ & $\begin{array}{c}90.8 \% \\
(784)\end{array}$ & $\begin{array}{c}88.9 \% \\
(55)\end{array}$ & $\begin{array}{c}91.4 \% \\
(61)\end{array}$ & $\begin{array}{l}79.2 \% \\
(101)\end{array}$ & $\begin{array}{c}86.2 \% \\
(88)\end{array}$ & $\begin{array}{c}90.8 \% \\
(785)\end{array}$ & $\begin{array}{c}89.3 \% \\
(1,089)\end{array}$ \\
\hline Hrs/Week on Studies Out of Class & $\begin{array}{l}22.0 \\
(284)\end{array}$ & $\begin{array}{l}23.5 \\
(772)\end{array}$ & $\begin{array}{l}21.9 \\
(52)\end{array}$ & $\begin{array}{l}23.6 \\
(57)\end{array}$ & $\begin{array}{l}19.8 \\
(99)\end{array}$ & $\begin{array}{l}23.6 \\
(79)\end{array}$ & $\begin{array}{c}23.6 \\
(775)\end{array}$ & $\begin{array}{c}23.0 \\
(1,062)\end{array}$ \\
\hline
\end{tabular}


Although differences are small, minority students have significantly more out-of-class contacts per month with teaching assistants and lab demonstrators than majority students: 2.3 as compared to 1.9 contacts. In addition, differences based on race are statistically significant. The greatest number of contacts, 3.1 per month, is had by students of East Indian origin; the least, 1.9, by students of European background. Differences among all groups, however, are small. It might be noted that students have more out-of-class contact with their professors than with teaching assistants and lab demonstrators, 3.2 compared to 2.0 contacts per month.

Statistically significant differences based on status and race also exist with regard to staff contacts. Minority students report an average of 2.4, majority students only 1.7. Among minorities students of East Indian background report the greatest number of contacts (2.6) and students of European origin the least (1.6). Differences based on status and race are statistically significant.

For participation in non-mandatory academic activities, the number of hours per week spent on campus, the number of current courses enrolled in, the number of courses dropped, the percentage of lectures attended, and the number of hours per week spent on studies outside of class, differences based on status and race are not statistically significant. In essence, over a wide range of academic involvement activities students participate more or less equally.

An exception in this regard is the percentage of their tutorials or labs in which students participate, for which differences based on status are statistically significant. In this instance minorities only attend $85.2 \%$ of the time; majority students show up for $90.8 \%$ of their tutorials/labs. When race is examined it is seen that students of Chinese origin attend only $79.2 \%$ of their tutorials and labs. Differences among all other groups are slight.

\section{A Summary Measure}

From the foregoing it is difficult to obtain an overview of the amount of social and academic involvement on the part of students. As a result, because of the theoretical importance of each, summary measures were constructed that would enable a comparison both among groups of students and among different types of activities. In brief, mean z-scores were calculated for all of the variables, with the exception of percent of friends who are visible minorities, in Table 1 and for all of the variables in Table 2. Z-scores have a mean of zero and, for all practical purposes, high and low scores of +3 and -3 respectively.

Mean z-scores based on status are summarized in Graph 1. The graph indicates that overall visible minority students have more contacts with faculty, teaching assistants and lab demonstrators, and staff, than majority students. 
Graph 1

Z-Scores by Minority Status

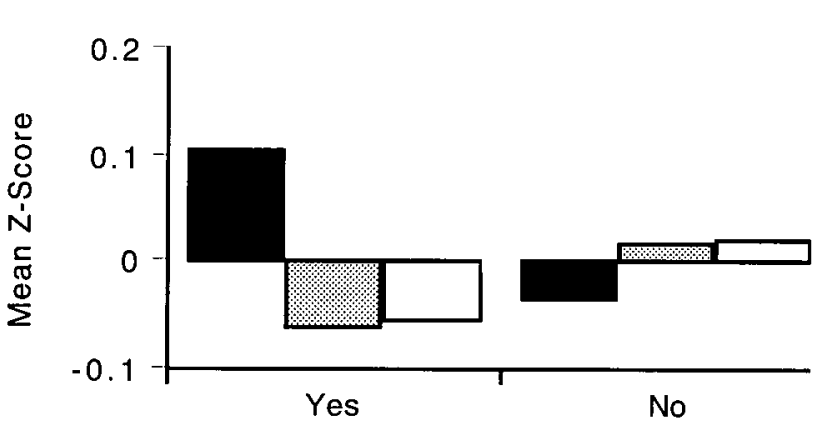

Contacts Fac./Staff

Academic Involve

$\square$ Social Involve

Visible Minority

F sig. .05 level Contacts, Academic Involvement

Graph 2

Z-Scores by Race

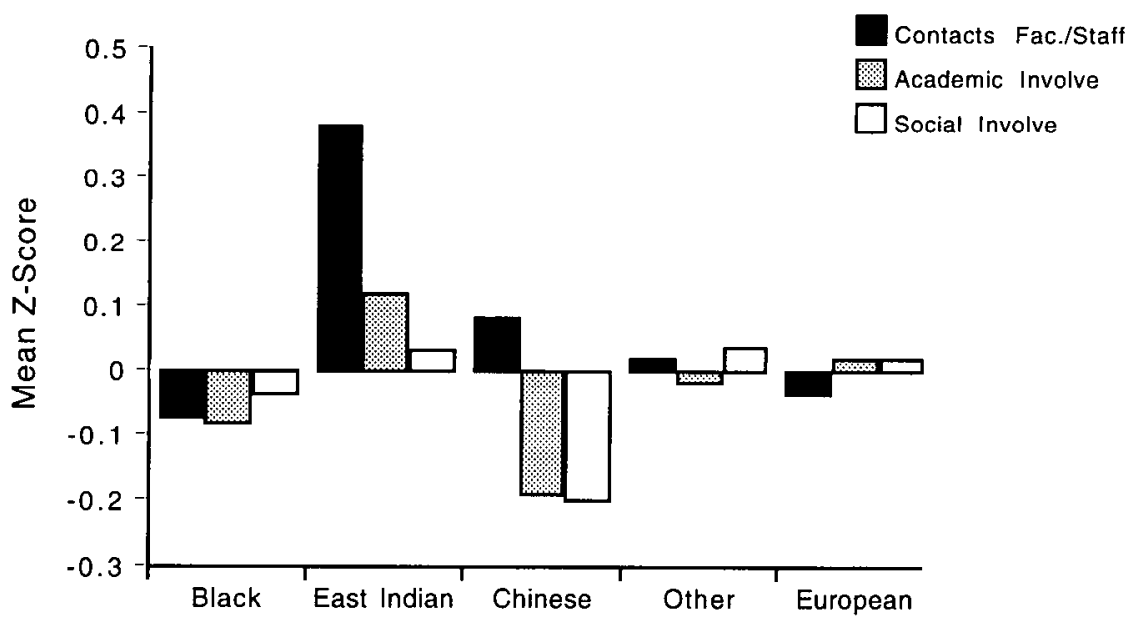

Race

F sig. .05 level all variables 
Moreover, differences for the F statistic are significant at the .05 level. Overall, however, majority students have more academic involvement than minority students. Once again, the differences are statistically significant. Although majority students have more social involvement than minorities, differences are not statistically significant. On the basis of these data it is difficult to argue that overall minority students at York University are any more, or any less, involved than majority students.

Differences based on race are summarized in Graph 2. Students of East Indian background have far more contact with faculty, teaching assistants, and staff than any other group. Equally apparent is the fact that Blacks and students of European descent have slightly less than average contacts. Differences along this dimension are statistically significant.

When academic involvement is examined it is evident that once again students of East Indian origin are at the top. By way of contrast, students of Chinese ancestry are the least involved academically. Blacks and 'others' are somewhat less involved than average while students of European origin have slightly higher than average involvement. Once again, these differences are statistically significant.

Statistically significant differences also exist with respect to social involvement. Students of East Indian and 'other' origins are most involved. Those of Chinese background and, to a lesser degree, Blacks are the least involved. The social involvement of students of European background is slightly above average.

Perhaps the clearest observation to emerge from Graph 2 is that overall students of East Indian origin are the most involved in York University. In addition, along two dimensions, those of Chinese ancestry are the least involved. Those of European and 'other' backgrounds are involved at an average level while the involvement of Blacks is slightly below average. Figures such as these make it difficult to argue that students of European origin are advantaged in terms of various types of involvement.

\section{Classroom Characteristics}

Classroom characteristics, or the way in which students experienced the formal instructional setting as measured in the February/March survey are outlined in Table 3. As noted earlier, a study of science students at York University has already revealed that satisfaction with instruction and believing that classroom topics are relevant to careers have positive implications for a number of outcomes. On this dimension status based differences are statistically significant with majority students (49\%) being slightly more satisfied than minority students (42\%). Race based differences, however, are not statistically significant. 
Table 3

Classroom Characteristics

\begin{tabular}{l|cc|cccccc} 
& \multicolumn{3}{|c}{ STATUS } & \multicolumn{9}{c}{ RACE } & Minority & Majority & Black & East Indian & Chinese & Other & European Row Total \\
\hline \multirow{2}{*}{ Satisfied Instruction* } & $42 \%$ & $49 \%$ & $47 \%$ & $45 \%$ & $41 \%$ & $38 \%$ & $49 \%$ & $47 \%$ \\
& $(128)$ & $(398)$ & $(27)$ & $(28)$ & $(42)$ & $(35)$ & $(400)$ & $(531)$ \\
Write English No Problem** & $75 \%$ & $86 \%$ & $84 \%$ & $74 \%$ & $65 \%$ & $81 \%$ & $86 \%$ & $83 \%$ \\
& $(209)$ & $(608)$ & $(48)$ & $(46)$ & $(58)$ & $(61)$ & $(610)$ & $(823)$ \\
Variety Perspective in Class*** & $64 \%$ & $66 \%$ & $74 \%$ & $65 \%$ & $49 \%$ & $71 \%$ & $66 \%$ & $65 \%$ \\
& $(161)$ & $(444)$ & $(39)$ & $(38)$ & $(37)$ & $(49)$ & $(446)$ & $(610)$ \\
Topics Relevant Career & $19 \%$ & $17 \%$ & $27 \%$ & $17 \%$ & $11 \%$ & $24 \%$ & $17 \%$ & $17 \%$ \\
& $(55)$ & $(124)$ & $(14)$ & $(10)$ & $(10)$ & $(21)$ & $(126)$ & $(181)$
\end{tabular}

* Chi-square sig. .05 level status

** Chi-square sig. 05 level status and race

*** Chi-square sig. .05 level race 
While its inclusion in this section is somewhat arbitrary, students' ability to write in English is targeted for analysis as it may be a precondition for gaining full benefit from classroom activities; in addition, this ability may only become manifest in the context of classroom related experiences. Data on English proficiency indicate that while the vast majority of students found no problem in writing in English, majority (86\%) more than minority students (75\%) could say that they had no difficulties in this regard. Also, proficiency in written English varied by race. While $86 \%$ of European origin and $84 \%$ of Black students encountered no problems with written English, only $65 \%$ of Chinese origin students could say the same thing. Among students of East Indian and 'other' origins $74 \%$ and $81 \%$ reported no difficulty in writing in English. Overall, while the differences are not always large, the data suggest that the classroom experiences of students of different backgrounds may not be the same.

At York, as on many other North American campuses, Eurocentrism and sexism in the curriculum are important issues. As a result, in the March survey students were asked to comment on the degree to which, where applicable, a variety of perspectives were put forward in their courses. Data presented in the table indicate that roughly equal percentages of both minority and majority students, $64 \%$ and $66 \%$ respectively, agree that courses offered sufficient variety in perspectives. When the same issue is examined by race, interesting and statistically significant differences emerge. Seventy four percent of Black students, more than for any other group, agree that a variety of perspectives were offered in their courses. By comparison, only $49 \%$ of students of Chinese origin had a similar view. The comparable figures for individuals of East Indian, European, and 'other' origins are $65 \%, 66 \%$, and $71 \%$. On the basis of these data it can be concluded that Blacks and 'others' more than students of European origin believe that they are being exposed to a variety of perspectives in classes. The feeling of students of East Indian origin on this matter is the same as that of European origin students. Only students of Chinese descent are less satisfied than students of European ancestry with perspectives provided in the classroom.

When the issue of class topics being relevant to career success is examined it is clear that few students of any status or racial group believe that course topics were career relevant. The small differences among groups that are evident are not statistically significant.

\section{First Year Outcomes}

In part, first year outcomes can be viewed as the result of the university experience, various aspects of which have been examined in previous sections. As a result, information collected on outcomes is extremely important. 
In the February/March survey information was collected on a number of outcomes; however, analyses in this study will be restricted to three measures collected in the survey (self-assessed intellectual development, increase in knowledge, and likelihood of returning to York) and one (final marks adjusted for OAC marks) obtained from the survey and administrative records. Information on these measures is summarized in Table 4.

As can be seen from Table 4, only $62 \%$ of minority students, compared to $74 \%$ of majority students, agreed that they had developed intellectually in their first year at university. Differences based on status for this measure are statistically significant. When race is examined, however, it can be seen that there are considerable differences within the minority group. Students of European origin and Blacks agree that they have developed intellectually, $75 \%$ and $74 \%$ respectively, to a far greater degree than students of East Indian and Chinese backgrounds, 53\% and 52\%. Seventy percent of 'others' also believe that they have developed intellectually over the first year. These differences based on race are statistically significant and suggest that the previously noted differences between minority and majority students on this dimension are a function of the low percentages of East Indians and Chinese origin students who believe that they have experienced intellectual development.

Statistically significant differences also exist between minorities and others in terms of the number who agree that independent of marks their knowledge increased over the first year: $76 \%$ of minorities compared to $85 \%$ of majority students agree that their knowledge increased. Once again, however, if race is examined, it can be seen that such differences are a result of relatively low levels of agreement on the part of students of East Indian and Chinese origin, only $71 \%$ and $73 \%$ of whom agree that their knowledge has increased. By way of contrast, $86 \%$ of students of European origin feel that their knowledge has increased. Eighty percent of Blacks and 78\% of 'others' also believe that their knowledge has increased. Differences based on race are statistically significant.

In terms of future plans, it is clear that the intention to return to York for the second year of studies varies by neither status nor race. Overall, $63 \%$ of students state that it is extremely likely that they will return to York.

Of all outcome measures, first year marks as obtained from administrative records vary consistently in terms of status and race. The first year grade point averages (not shown in the table) for minorities is 5.0 and 5.6 for majority students. The GPAs for Blacks and students of East Indian, Chinese, 'other' and European origins are 4.8, 5.4, 5.1, 4.9, and 5.6. Differences based on status and race, although not large in absolute terms, are statistically significant. 


\begin{tabular}{|c|c|c|c|c|c|c|c|c|}
\hline & \multicolumn{2}{|c|}{ Status } & \multicolumn{6}{|c|}{ RACE } \\
\hline & Minority & Majority & Black & East Indian & Chinese & Other & European & Row Total \\
\hline Agree Developed Intellectually* & $\begin{array}{c}62 \% \\
(172)\end{array}$ & $\begin{array}{c}74 \% \\
(587)\end{array}$ & $\begin{array}{l}74 \% \\
(39)\end{array}$ & $\begin{array}{l}53 \% \\
(32)\end{array}$ & $\begin{array}{l}52 \% \\
(44)\end{array}$ & $\begin{array}{l}70 \% \\
(60)\end{array}$ & $\begin{array}{c}75 \% \\
(590)\end{array}$ & $\begin{array}{c}71 \% \\
(765)\end{array}$ \\
\hline Agree Increased Knowledge* & $\begin{array}{c}76 \% \\
(228)\end{array}$ & $\begin{array}{c}85 \% \\
(687)\end{array}$ & $\begin{array}{l}80 \% \\
(44)\end{array}$ & $\begin{array}{l}71 \% \\
(43)\end{array}$ & $\begin{array}{l}73 \% \\
(72)\end{array}$ & $\begin{array}{l}78 \% \\
(70)\end{array}$ & $\begin{array}{l}86 \% \\
(692)\end{array}$ & $\begin{array}{l}83 \% \\
(921)\end{array}$ \\
\hline Extremely Likely Return York & $\begin{array}{c}61 \% \\
(179)\end{array}$ & $\begin{array}{c}64 \% \\
(509)\end{array}$ & $\begin{array}{l}58 \% \\
(32)\end{array}$ & $\begin{array}{l}70 \% \\
(42)\end{array}$ & $\begin{array}{l}57 \% \\
(56)\end{array}$ & $\begin{array}{l}64 \% \\
(54)\end{array}$ & $\begin{array}{c}64 \% \\
(507)\end{array}$ & $\begin{array}{c}63 \% \\
(691)\end{array}$ \\
\hline GPA Adjusted for OAC Marks ${ }^{\Delta}$ & $\begin{array}{c}5.09 \\
(216)\end{array}$ & $\begin{array}{c}5.47 \\
(632)\end{array}$ & $\begin{array}{l}4.97 \\
(39)\end{array}$ & $\begin{array}{l}5.21 \\
(48)\end{array}$ & $\begin{array}{l}5.08 \\
(80)\end{array}$ & $\begin{array}{l}5.12 \\
(50)\end{array}$ & $\begin{array}{c}5.46 \\
(631)\end{array}$ & $\begin{array}{c}5.37 \\
(848)\end{array}$ \\
\hline
\end{tabular}

* Chi-square sig. .05 level status and race

$\Delta \quad$ F sig. .05 level for main effects and covariate 
As seen in Table 4, when controls are made for OAC marks, the first year grade point average for minorities is $\mathbf{5 . 0 9}$ and 5.47 for majority students. Differences are statistically significant. If race is examined it can be seen that when OAC marks are controlled students of European origin achieve the highest GPAs, 5.46, and Black students the lowest, 4.97. In ascending order students of Chinese, 'other', and East Indian origins score 5.08, 5.12, and 5.21. While differences based on race are statistically significant, it must be emphasized that differences between the highest and lowest group translate into only a $2 \%$ difference $67.6 \%$ for Blacks compared to $69.8 \%$ for students of European origin.

\section{Relations Among Environmental Factors (Experiences), Race, and Outcomes}

So far in this study a number of things have been established:

a. Although York students in general do not come from affluent backgrounds, the families of majority students are better off financially than the families of minority students.

b. Contact with faculty, teaching assistants and lab demonstrators, and staff; aspects of academic involvement; and social involvement, also vary by status and race. Once again differences do not always favour students of European origin.

c. Some classroom experiences differ by status and/or race. Differences, however, are often slight.

d. While certain outcomes of the first year experience do not always favour students of European background, those of European origin do achieve slightly higher marks than individuals who can be classified as minority students.

What has not been established is the potential relationship among background characteristics, university experiences, race, and specific outcomes of the university experience as identified earlier in the discussion of the 'outcomes model'. Attention will now focus on the results of a series of regression analyses designed to deal with this problem.

Variables included in the regressions, and the order of block entry, are listed below. Within blocks a stepwise procedure with pairwise deletion was used.

\section{Pre-Entry (Background) Characteristics}

Father's and mother's education $(0=$ not completed college/university; 1 = completed college/university); OAC marks in percentages; and gender $(0=$ female; $1=$ male $)$. 


\section{Environmental Factors (University Experiences)}

a. Social and Academic Involvement: contacts (average $\mathrm{z}$-scores for contacts with faculty, teaching assistants and lab demonstrators, and staff); academic involvement (average $\mathrm{z}$-scores for academic involvement); and social involvement (average $z$-scores for social involvement).

b. Classroom Characteristics: satisfaction with instruction $(0=$ not satisfied, $1=$ satisfied); write English with no $\operatorname{problem}^{5}(0=$ no, $1=$ yes); variety of perspectives presented in class $(0=$ no, $1=$ yes $)$; relevance of class topics to future career success $(0=$ no, 1 = yes).

\section{Race}

Black $(0=$ no, $1=$ Black); East Indian ( $0=$ no, $1=$ East Indian); Chinese $(0=$ no, $1=$ Chinese $)$ 'other' $(0=$ no, $1=$ 'other'). European is the reference category.

\section{Outcomes}

Developed intellectually and increased in knowledge $(1=$ low to $5=$ high); likelihood of returning to York $(1=$ low to $6=$ high); GPA $(1=$ low to $10=$ high). The decision of which variables to include in the analyses was based on a considerable amount of research that has been carried out in the realm of university outcomes as discussed earlier, the fact that existing research on science students at York has shown that classroom activities have important implications for a number of first year outcomes, and logic.

\section{Intellectual Development}

The results of the final equation of the regression analysis in which the student's self-assessed intellectual development was the outcome are summarized in Table 5. Table figures indicate that students' background characteristics do not affect the extent to which they develop intellectually. Among environmental factors, classroom characteristics, particularly satisfaction with instruction, have the greatest influence on intellectual development. In total, satisfaction with instruction, having course topics that are career relevant, being presented with a variety of perspectives, and having no problem writing English explain $13 \%$ of the total variance.

While academic involvement and contacts with faculty etc. also affect intellectual development, the effect is minor. Both variables combined only contribute an additional $2 \%$ to the explained variance. 
Table 5

Outcome: Developed Intellectually (Range $=1$ to 5; Mean 3.2: S.D. $=9$ )

\begin{tabular}{l|ccc} 
& b & R-square & Beta \\
\hline Satisfied Instruction & .39 & .08 & .21 \\
Course Topics Relevant to Career & .34 & .11 & .14 \\
Variety Perspectives in Class & .25 & .12 & .13 \\
No Problem Writing English & .23 & .13 & .09 \\
& & & \\
Academic Involvement & .20 & .15 & .11 \\
Contacts Faculty, etc. & .12 & .15 & .10 \\
& & & \\
East Indian Origin & -.30 & .16 & -.07
\end{tabular}

Minimum number cases $=707$

Maximum number cases $=1,083$

Table 6

Outcome: Increased Knowledge $($ Range $=1$ to $5 ;$ Mean 4.2; S.D. $=9$ )

\begin{tabular}{l|ccc} 
& b & R-square & Beta \\
\hline Satisfied Instruction & .34 & .07 & .19 \\
Variety Perspectives in Class & .32 & .11 & .17 \\
Course Topics Relevant to Career & .29 & .12 & .12 \\
& & & \\
Chinese Origin & -.23 & .13 & -.08
\end{tabular}

Minimum number cases $=707$

Maximum number cases $=1,083$ 
Perhaps most important in terms of the objective of this study is that being East Indian in origin has a negative effect on self-assessments of intellectual development. Although the effect is small, contributing only $1 \%$ to the total variance, it indicates that even when the effects of the preceding variables listed in the table are taken into consideration students of East Indian origin believe that they have developed less intellectually than individuals of European origin. Unfortunately, the data do not allow explanations of why this is the case.

In total, the variables included in the regression explain $16 \%$ of the total variance in intellectual development.

\section{Increased Knowledge}

Data outlined in Table 6 once more point to the importance of classroom characteristics in explaining particular outcomes. In this instance, being satisfied with instruction, being presented with a variety of perspectives, and being exposed to career relevant topics in class explain $12 \%$ of the variance in increased knowledge.

Table data also indicate that after the effects of the previous three variables have been take into consideration, being of Chinese origin has a negative effect on self-assessments of intellectual development. The variance explained by this variable, however, is only $1 \%$. As was the case for Table 5 , it is difficult to explain why this is so.

\section{Return to York}

As can be seen from the figures in Table 7, a background variable, having a mother who completed college or university, has a positive but small impact (it only explains $1 \%$ of the variance) on the intent to return to York University. Once again the environmental variables, being exposed to career relevant topics in class and being presented with a variety of perspectives in class, affect the outcome; however, in combination they only explain an additional $1 \%$ of the variance. Indeed, all of the variables in the equation only explain $2 \%$ of the total variance. It might be noted, however, that no race variables have an impact on the likelihood of returning to York.

\section{First Year GPA}

As noted earlier, there are very slight yet statistically significant differences in GPA based on race. As seen in Table 8 the background variable OAC average explains $18 \%$ of the total variance. A further $1 \%$ of total variance is explained by having a father with a college/university education.

Of the environmental variables, being satisfied with instruction explains an additional $2 \%$ of the variance and academic involvement $3 \%$. While social 
Table 7

Outcome: Return to York (Range $=1$ to 6; Mean 5.4; S.D. $=.9$ )

\begin{tabular}{l|ccc} 
& b & R-square & Beta \\
\hline Mother College/University & .20 & .01 & .08 \\
& & & \\
Course Topics Relevant to Career & .23 & .02 & .09 \\
Variety Perspectives in Class & .15 & .02 & .08
\end{tabular}

Minimum number cases $=707$

Maximum number cases $=1,083$

Table 8

Outcome: First Year GPA (Range $=1$ to $10:$ Mean 5.5; S.D. $=1.6$ )

\begin{tabular}{l|ccc} 
& b & R-square & Beta \\
\hline OAC Average & .09 & .18 & .38 \\
Father College/University & .30 & .19 & .08 \\
& & & \\
Satisfied Instruction & .45 & .21 & .14 \\
& & & \\
Academic Involvement & .76 & .24 & .24 \\
Social Involvement & -.39 & .26 & -.14
\end{tabular}

Minimum number cases $=707$

Maximum number cases $=1,083$

involvement explains an additional $2 \%$ of the variance, its effect is negative. In other words, increased social involvement decreases first year GPA. This was an unexpected finding. Overall, variables in the regression explain $26 \%$ of the variance in GPA.

As no race variables entered the regression it can be safely assumed that students of various races do not receive different marks because of race per se. It is more likely that the differences among students of various races in terms of outcomes as observed in Table 4 are a result of different high school marks, 
fathers' education that might affect the intellectual orientation of the home, satisfaction with instruction, and academic and social involvement. ${ }^{6}$

\section{Conclusion}

The results of the regressions lead to a number of conclusions:

a. Although in Table 4 it was clear that several outcomes of the first year experience varied somewhat by race, once a number of other possible variables that can affect outcomes have been taken into consideration, race is only significant in explaining self-assessed intellectual development and increases in knowledge. Moreover, the impact of race variables on these two outcomes is minimal and pertains only to students of East Indian and Chinese origin.

b. Findings such as these suggest that if students of different races manifest different outcomes it is because of different levels of achievement in high school, types of classroom experiences, differential problems with writing English, differential rates of contact with faculty etc., and, where appropriate, different rates of academic and social involvement. It is unlikely a result of race per se.

c. Gender has an impact on none of the outcomes under discussion.

d. In terms of interventionist strategies these findings suggest that attention should focus particularly on enhancing the classroom experience and increasing both faculty etc., contact and academic involvement. Steps taken in these directions would be of benefit to all students, independent of race.

\section{The Experiences That Count}

From the foregoing regression analyses it was evident that three classroom experience variables - satisfaction with instruction, variety of perspectives presented in class, and presentation of class topics relevant to careers - had an impact on one or more of the outcomes. ${ }^{6}$ Similarly, contacts with faculty (etc.) and academic involvement also had affects on one or more of the outcomes.

In order to determine the overall way in which different racial groups experienced the classroom, z-scores were calculated for each of the three classroom experience variables. The mean $z$-score for the three variables was then calculated (classroom characteristics). Next, to summarize contacts with faculty and academic involvement, the $\mathrm{z}$-scores for these two variables were averaged (contacts/ involve). The distribution for each mean by race is presented in Graph 3 . 
From the graph it can be concluded that the classroom characteristics experienced by Black students were higher than average; however, their contacts/involvement were lower than the mean. By way of comparison, classroom characteristics of students of East Indian ancestry were slightly lower than the mean and contacts/involvement far higher. For students of Chinese descent, both classroom characteristics and contacts/involvement were lower than average. This underlying pattern was evident when the standing of students of Chinese origin was examined in tables discussed earlier. Moreover, the pattern suggests that students of Chinese origin have the most negative experiences. By way of comparison, for students of 'other' and European origin, classroom characteristics and contacts/involvement are more or less similar and about average.

Differences indicate that on important dimensions the first year environment is experienced differently by students of different races; however, with the exception of the negative situation of students of Chinese origin, it is very difficult to provide overall positive or negative characterizations of group experiences. Does, for example, the high classroom characteristics standing of Blacks cancel out their low standing on contacts/involvement? Does the high standing on contacts/involvement cancel out the below average standing on classroom characteristics for those of East Indian ancestry? It is impossible to say.

Despite these ambiguities, the data do suggest that interventions that would improve the classroom experience and increase contacts and promote academic integration would be of benefit, in varying degrees, to students of different racial origins. With regard to this objective a question was asked of students in the March survey that focused on opinions regarding a "compulsory first year credit course that would cover subjects such as: university standards, criteria, and procedures; effective studying; time management; improving writing; stress management; and jobs in the field in which you are majoring." The question was asked because a mounting body of information indicates that such courses both assist individuals in gaining the most from the classroom experience and in making contacts with faculty and staff (Upcraft and Gardner, 1989). Obviously, measures such as these do not relieve faculty from doing a good job in the classroom in later courses.

Survey data indicate that a majority of minority and majority students (59\% and $56 \%$ respectively) feel that such a course would be a good, or a very good use of time. Among minorities, however, $77 \%$ of Black students and $63 \%$ of students of East Indian origin support the offering of such a course. Surprisingly, the only group in which fewer than a majority $(45 \%)$ favour such 


\section{Graph 3}

Classroom Characteristics and Academic Integration by Race

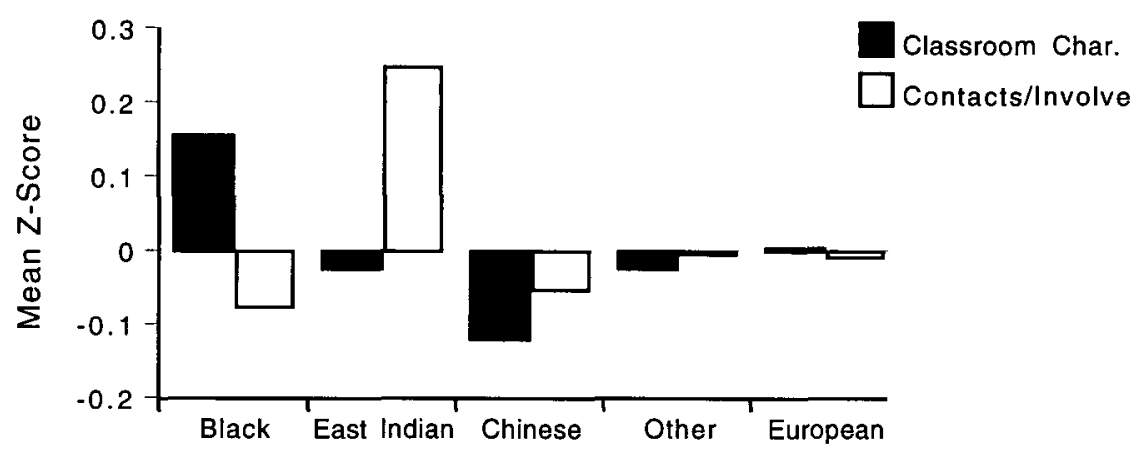

Race

F sig. at .05 level both levels

a course is students of Chinese origin. Nonetheless, support is sufficiently high in other quarters to suggest that such an option might be tried at York.

\section{Conclusion}

The conclusion to this study can be stated very briefly. As in the United States, minority students entering York University come from more financially disadvantaged families than non-minority students. However, in contrast to much of the research carried out in the United States, the experiences of minorities in the first year are not all negative and the experiences of majority students are not all positive. Considerable variation exists from experience to experience and from one racial group to the other. In addition, while university experiences have implications for certain first year outcomes, race per se has only a marginal impact on a couple of outcomes. As a result, at least with regard to the first year experience, there is a considerable degree of racial equality in outcomes.

This does not mean that there is no room for improvement. To the degree that, for example, the offering of a variety of perspectives in class contributes to desired outcomes for certain groups, steps should be taken to encourage curricular variety. The same argument can be made for a satisfying instructional experience, being exposed to topics relevant to careers, contacts with-faculty (etc.) and increasing academic involvement. 
It cannot be suggested that the situation at York University with respect to the matters raised in this study is typical of all Canadian universities. Research is required at other Canadian institutions before legitimate comments can be made in this regard. Similarly, on the basis of one study of one Canadian university it cannot be argued that the situation in this country is different than that in the United States. Once additional research has been carried out in other Canadian universities it will be possible to comment on this possibility with more certainty.

\section{Notes}

1 Parts of this article were taken from a working paper entitled, Race on Campus: Outcomes of the First Year Experience at York University.

2 With the exception of the background characteristics that are taken from the September survey, most of the data for the current article were taken from the survey conducted in February and March. More details on the September survey can be found in Grayson (1994b).

3 The total number of students classified as 'majority' is sometimes slightly lower than the total number of European origin. This is because some students from European backgrounds (e.g., Sicilian, Greek) defined themselves as visible minorities. In fact, focus group studies (Grayson, 1994c, 1994d) indicate that many students identify darkskinned people from Mediterranean countries as visible minorities.

4 In Table 1, the total numbers for status are fewer than for race due to missing data.

5 Being able to write with no problem is treated as a classroom characteristic rather than a pre-entry characteristic because once exposed to the university environment many students who formerly had confidence in this regard changed their minds. In essence, judgements relating to ability to write in English is an emergent phenomenon.

6 In the preceding regressions, pairwise deletion of missing data was used. Slightly different results were obtained when listwise deletion and mean substitution were used. Regressions using each nonetheless led to the inescapable conclusions that classroom characteristics and academic involvement made major contributions to the outcomes under study and race had very little, if any, impact on outcomes. These general conclusions are more important than the impact of any single variable in individual regressions.

7 Having no problems writing in English also had an effect; however, because of its emergent nature, it is not included here.

\section{References}

Ashar, H., \& Skenes, R. (1993). Can Tinto's student departure model be applied to nontraditional students? Adult Education Quarterly, 43(2).

Astin, A. W. (1991). Assessment for excellence. Toronto: Collier Macmillan.

Astin, A. W. (1993). What matters in college. San Francisco: Jossey Bass. 
Astin, A. W., \& Astin, H. S. (1992). Undergraduate science education. Los Angeles: HERI, University of California.

Beer, C. T., \& Darkenwald, G. G. (1989). Gender differences in adult student perceptions of college classroom social environments. Adult Education Quarterly, 40(1).

Benjamin, M. (1990). Freshman daily experience. Guelph: University of Guelph. Student Development Monograph Series, Vol. 4.

Benjamin, M. (1994). Educational equity: A profile of designated groups (draft). Guelph: Student-Environment Study Group, University of Guelph.

Centra, J., \& Rock, D. (1971). College environments and student academic achievement. American Educational Research Journal, 8, 623-634.

Chickering, A. (1974). Community versus residential students. San Francisco: Jossey Bass.

Darkenwald, G. G., \& Gavin, W. J. (1987). Dropout as a function of discrepancies between expectations and actual experiences of the classroom social environment. Adult Education Quarterly, 37(3).

Dietsche, P. (1990). Freshman attrition in a college of applied arts and technology of Ontario. Canadian Journal of Higher Education, 20(2).

Endo, J., \& Harpel, R. (1983). Student-faculty interaction and its effect on freshman year outcomes at a major state university. Paper presented to the meetings of the Association of Institutional Research, Toronto.

Grayson, J. P. (1994a). First year science in a commuter university: Where to intervene. Canadian Journal of Higher Education, 24(2).

Grayson, J. P. (1994b). Race on campus: Outcomes of the first year experience at York University. Toronto: Institute for Social Research, York University.

Grayson, J. P. (1994c). The social construction of 'visible minority' for students of chinese origin. Toronto: Institute for Social Research, York University.

Grayson, J. P. (1994d). 'Racialization' and Black student identity at York University. Toronto: Institute for Social Research, York University.

Hurtado, S. (1992). The campus racial climate. Journal of Higher Education, 63(5).

Jackson, K. W., \& Swan, L. A. (1991). Institutional and individual factors affecting Black undergraduate student performance: Campus race and student gender. In W. R. Allen et al. (eds.), College in Black and White. Albany: State University of New York Press.

Langenbach, M. \& Aagard, L. (1990). A factor analytic study of the adult classroom environment scale. Adult Education Quarterly, 40(2).

Loo, C., \& Rolison, G. (1986). Alienation of ethnic minority students at a predominantly White university. Journal of Higher Education, 57(1).

Nettles, M. T. 1991. Racial similarities and differences in the prediction of college student achievement. In W. R. Allen et al. (eds.), College in Black and White. Albany: State University of New York Press.

Pascarella, E., Duby, P., \& Iverson, B. (1983a). A test and reconceptualization of a theoretical model of college withdrawal in a commuter institution setting. Sociology of Education, 56, 88-100. 
Pascarella, E., Duby, P., Terenzini, P., \& Iverson, B. (1983b). Student-faculty relationships and freshman year intellectual and personal growth in a nonresidential setting. Journal of College Student Personnel, 24, 395-402.

Pascarella, E., \& Terenzini, P. (1976). Informal interaction with faculty and freshman ratings of academic and non-academic experiences of college. Journal of Educational Research, 70, 35-41.

Pascarella, E., \& Terenzini, P. (1977). Patterns of student-faculty informal interaction beyond the classroom and voluntary freshman attrition. Journal of Higher Education, 48, 540-552.

Pascarella, E., \& Terenzini, P. (1979a). Interaction effects in Spady's and Tinto's conceptual models of college dropout. Sociology of Education, 52, 197-210.

Pascarella, E., \& Terenzini, P. (1979b). Student-faculty informal contact and college persistence: A further investigation. Journal of Educational Research, 72, 214-218.

Pascarella, E., \& Terenzini, P. (1991). How college affects students. San Francisco: Jossey Bass.

Patterson, A. M., Sedlacek, W. E., \& Perry, F. W. (1984). Perceptions of Blacks and Hispanics in two campus environments. Journal of College Student Personnel, November.

Samuel, T. J. (1992). Visible minorities in Canada: A projection. Toronto: CAF.

Sedlacek, W. E. (1987). Black students on White campuses: 20 years of research. Journal of College Student Personnel, November.

Smedley, B. D., Myles, H. F., \& Harrell, S. P. (1993). Minority status stresses and the college adjustment of ethnic minority freshmen. Journal of Higher Education, 64(4).

Student Environment Study Group. (1992). Educational equity and cultural diversity: A discussion paper. Guelph: University of Guelph.

University of Toronto. (1992). University of Toronto Bulletin. March 23.

Upcraft, M. L., \& Gardner, J. N. (Eds). (1989). The freshman year experience. San Francisco: Jossey Bass.

Volkwein, J., King, M., \& Terenzini, P. (1985). A study of the academic performance and intellectual growth of transfer students. Paper presented to the meeting of the Association for the Study of Higher Education, Chicago.

Welty, J. (1976). Resident and commuter students. Journal of College Student Personnel. 17, 465-68.

White, J. B., \& Sedlacek, W. E. (1987). White student attitudes toward Blacks and Hispanics: Programming implications. Journal of Multicultural Counselling and Development, 15, Oct. 